\title{
Reliability and Validity of a Scale to Measure Prejudice toward Old Order Amish
}

William M. McGuigan ${ }^{1}$

Associate Professor of Family Studies

The Pennsylvania State University-Shenango Campus

\begin{abstract}
Numerous studies have examined prejudice in regard to race, age, sexual orientation, and gender, among others. However, there remains a paucity of research on prejudice toward Christian religious groups. In particular, prejudice towards one of America's fastest growing religious groups, the Old Order Amish, is rarely examined. Using social categorization theory and based on McConahay's modern and old-fashioned racism scale, an “Attitude Toward Amish” scale is developed and tested. Factor analysis revealed one dominant component and high internal reliability. The article concludes with a discussion of implications for future research of this rapidly growing population.
\end{abstract}

\section{Keywords}

Amish; prejudice; Attitude Toward Amish scale; social categorization theory 


\section{Introduction}

Numerous studies have examined prejudice in regard to race, age, sexual orientation, and gender (Aberson, Swann, and Emerson 1999; Chasteen and Pratt 1999; Gassner and McGuigan [forthcoming]). However, despite the fact that "the importance of religious commitments and religious organizations to American society increased over the last several decades” (Jenness, Smith, and Stepan-Norris 2007, vii) there remains a paucity of research on prejudice toward Christian religious groups. In particular, prejudice towards one of America's fastest growing religious groups, the Old Order Amish, is rarely examined.

Today there are well over 275,000 Amish of various sects living in at least 29 U.S. states, with the majority living in Pennsylvania, Ohio, and Indiana (Donnermeyer, Anderson, and Cooksey 2013). Since 2009, approximately 80 new Amish settlements have been started (Donnermeyer and Luthy 2013). This rapid growth can be traced to the fact that Amish marry young and are a high fertility group, having an average of eight children, with approximately 90\% of the children remaining in the Amish faith (Cooksey and Donnermeyer 2004; Greska 2002).

Devotion to their faith includes adherence to unique identity markers (e.g. plain dress, Pennsylvania Deitch language, and horse and buggy mode of transportation). This uniqueness reinforces their religious conviction to be separate from the modern world, but also elicits special attention from the non-Amish. In addition, the Amish ways of conformity and humility contrast with the American ways of individuality and pride, increasing the social distance between the Amish and non-Amish. These differences make the Amish a group with whom it is difficult to share social contact, contributing to the misconceptions and prejudice that some non-Amish hold toward their Old Order Amish neighbors.

\section{Measuring Prejudice}

Gordon Allport's (1954) seminal book The Nature of Prejudice was highly influential in early studies of prejudice based on cultural differences. Initial studies viewed prejudice as a symptom of individual pathology. Later the focus shifted away from individual pathology to the macro-level influence of social categorization on prejudicial attitudes. Following this trend, McConahay’s (1986) classic “Old-Fashioned and Modern Racism” scale provided a comprehensive measure of both overt and covert prejudice, primarily towards African Americans. Since then, this measure has been adapted to examine prejudice toward other ethnic and oppressed groups, such as Asians, Hispanics, homosexuals, women, and members of the Jewish faith (Dunbar 1995; Fu 2005; Henry and Sears 2008; Swim, Aikin, Hall, and Hunter 1995).

For the current study, prejudice refers to negative attitudes based on preconceived notions of select groups with the assumption that all members of a particular group can be categorized 
with the same negative characteristics. "Social Categorization Theory” (Wittenbrink, Hilton, and Gist 1998) explains how groups are then organized into in-group and out-group formations or an "us or them” way of thinking. Byers and Crider (2002) reported misconceptions and prejudice have led to harassment, intimidation, and violence towards one cultural / religious group, the Amish. They stated that "perceptions of separation based on lifestyle and culture have been a common historical reason for prejudice and poor treatment of others who are considered members of a societal out-group. The Amish follow this pattern” (141).

Despite the growing presence of this unique group, an in-depth search of the published research found only one study of non-Amish prejudice toward Old Order Amish. The study by McGuigan and Scholl (2007) provides the only single known instrument specifically designed to measure prejudice toward the Amish, the 17-item "Attitude Toward Amish" (A.T.A.) scale. The A.T.A. is generally modeled after McConahay’s (1986) “Modern and Old-fashioned Racism” scale in that it measures both the overt and covert prejudicial attitudes of the non-Amish toward the Amish (rather than white people's prejudice toward African Americans). Items include "I would like having an Amish family for neighbors" and "Amish people have an offensive odor about them" (see entire scale in Appendix 1). Items are scored using the same five-point Likert scaling range as McConahay's scale, from one (strongly disagree) to five (strongly agree). Some items are reverse-scored so that higher scores indicate more positive attitudes (i.e. less prejudice).

\section{Methods and Results}

The goal of the current research was to assess the reliability and validity of the 17-item A.T.A. scale using three distinct samples. First, 64 primarily white, middle class, female undergraduate psychology students attending a private university in northwestern Pennsylvania completed the A.T.A. scale. To determine test-retest reliability, Pearson correlations were calculated between pre- and post-test scores. A strong and statistically significant correlation ( $r=0.61, p<.001$ ) demonstrated that the 64 student's scores on the A.T.A. were stable over time. Inter-item reliability was assessed using Cronbach's alpha, showing that the A.T.A. scale had internal consistency within acceptable limits $(\alpha=0.62)$.

A factor analysis with varimax rotation was conducted to examine the validity of the A.T.A. scale. Two components were defined for the A.T.A. scale. The dominant component consisted of 13 items with factor loadings ranging from 0.52 to 0.77 . This component was grouped by items that defined the Amish as ordinary folks. Items included "I would like having an Amish family for neighbors.” The second component consisted of four items with high factor loadings ranging from 0.69 to 0.77 . This component seemed to reflect Amish intelligence. Items included "Intelligence of the Amish ranges from very slow to average to very intelligent." All 17 items on the A.T.A. scale had high face validity providing further evidence that the A.T.A. scale was a valid instrument for assessing prejudice toward the Amish. 
A second convenience sample was drawn from a small town central to a large Old Order Amish community in northwestern Pennsylvania. Approximately 450 Amish families constituted one-fifth of the local population, providing non-Amish residents repeated exposure to the Amish and ample opportunities for interaction. As part of a larger study, one male and two female undergraduate psychology students (blind to the study) stood in front of the local feed store, farm supply store, and grocery store and distributed anonymous surveys that were completed on the spot by 25 male and 64 female non-Amish adults $(n=89)$. Subjects ranged from 18 to 64 years of age $(M=25.75)$ with education normally distributed from some high school to college degrees ( $M=13.84$ years of education). Nearly all were white non-Hispanic (96\%), matching the racial composition of the local area.

In this second sample, the A.T.A. demonstrated high internal reliability $(\alpha=0.78)$. Pearson's correlations revealed that the A.T.A. scale was significantly correlated with other established measures in the expected directions. The A.T.A. scale had a statistically significant negative correlation ( $r=-0.25, p<.05)$ with a measure of a person's preference for inequality between social groups, the "Social Dominance Orientation” (S.D.O.) scale (Pratto, et al. 1994). The A.T.A. scale had a significant positive correlation $(r=0.23, p<0.05)$ with the "Belief in Equality Inventory” (Gray, Connor, and Decatur 1994). These moderate but statistically significant correlations provide strong evidence of the construct validity of the A.T.A. scale.

A third trial consisted of a convenience sample of 74 junior and senior college students enrolled in the "Human Development and Family Studies" program at a major public university in the northeastern United States. The students were primarily white (89\%) females (77\%) from working class backgrounds. In addition to completing the A.T.A. scale, the students completed an established measure of prejudice towards all religious groups, the nine item religious prejudice subscale of the "Modified Godfrey-Richman I.S.M.” scale (M-GRISMS) (Godfrey, Richman, and Withers 2000). The M-GRISMS has shown high reliability and validity with college students. Items on the M-GRISMS religious subscale included "Christians are intolerant of people with other religious beliefs.” Items were scored 0 (disagree) and 1 (agree), with higher scores indicating a greater level of prejudice toward all religious groups.

Based on Cronbach's alpha the A.T.A. scale showed high internal consistency $(\alpha=0.80)$ in this sample of 74 students. The A.T.A. scale also had a strong and statistically significant negative correlation with the M-GRISMS religious prejudice subscale ( $r=-0.40, p<.001)$. Mean scores on the A.T.A. scale decreased (showing greater prejudice) with each additional item that students agreed with on the M-GRISMS subscale of religious prejudice. This correlation demonstrates the predictive validity of the A.T.A. scale. Together, these three analyses indicate that the A.T.A. scale is a reliable and valid measure of prejudice toward Old Order Amish.

\section{Discussion and Implications for Future Research}

The A.T.A. scale provides a brief and easy way to administer assessments that can be 
used by researchers and community practitioners to identify individuals' attitudes toward this fast growing religious sect. With their rapid population increase, the Amish are starting settlements in a number of new locations where they have never lived before. This spread of new communities potentially creates "flash points" at each new locality and will likely do so for the foreseeable future. Researchers could use the A.T.A. scale to identify non-Amish prejudice at these probable flash points and provide community practitioners a valid basis to begin a variety of discussions around religious tolerance and community development. In this way, the A.T.A. scale provides an additional feature of particular salience. Researchers could track factors that may reduce nonAmish prejudice over time (e.g. increased social contact, knowledge, and economic partnerships). A reduction in prejudice is an important aspect of community development that has so far received very little attention.

Certainly an awareness of prejudice is the logical first step toward building community cohesion and increasing understanding between the Amish and non-Amish. Building community cohesion can be particularly important in small farming communities where Amish adherence to their faith has been questioned by their non-Amish neighbors and local authorities. For example, nine Amish from the Swartzentruber Amish sect in Kentucky were sentenced to jail for refusing to place triangular orange safety signs on their horse-drawn buggies. The Swartzentruber's stated that strict adherence to their religion forbids the use of bright colors (Leibowitz, 2011). Although they subsequently received an exemption through proceedings initiated by the Kentucky State Legislature, their actions were seen as a disregard for safety that angered some of their nonAmish neighbors. Likewise, in central Pennsylvania a sewage dispute dragged on for years between the Amish and the Cambria County Sewage Enforcement Agency. An inability to understand the opposing party's concerns resulted in a stalemate, with all members of this Amish group leaving Pennsylvania (Mandak 2012). Recent issues involving the deep well drilling for natural gas have created land use questions for both Amish and non-Amish farmers in Ohio and Pennsylvania (Scheyder 2013). Other arguments over land usage have resulted in harassment and even physical violence toward the Amish (Byers and Crider 2002).

It is the author's hope that the A.T.A. scale will become a useful tool for assessing community interrelations in Amish and other plain communities and that it can be used by researchers and community practitioners to identify and negate potential confrontations. Further tests of reliability and validity are encouraged using larger and more diverse samples. Although the A.T.A. scale was designed to measure prejudice toward Old Order Amish (and not other ethnically based religious minorities), it could easily be modified to assess prejudice toward any of the many other plain Anabaptist groups (see Anderson 2013). Such studies would be especially enlightening. As we move through the twenty-first century and the population and diversity of "plain people" increases, the need to understand the intersection of the divergent views of others becomes increasingly important. 


\section{Endnote}

${ }^{1}$ Contact information: William M. McGuigan, Associate Professor of Family Studies, The Pennsylvania State University—Shenango Campus, 147 Shenango, Pennsylvania 16146; 724983-2914 wmm11@psu.edu.

\section{References}

Aberson, Christopher, Joye Swan, and Eric Emmerson. 1999. "Covert Discrimination against Gay Men by U.S. College Students.” Journal of Social Psychology 139(3):323-35.

Allport, Gordon. 1954. The Nature of Prejudice. Cambridge: Addison-Wesley.

Anderson, Cory. 2013. "Who Are the Plain Anabaptists? What Are the Plain Anabaptists?” Journal of Amish and Plain Anabaptists Studies 1(1):26-71.

Byers, Bryan D. and Benjamin W. Crider. 2002. "Hate Crimes Against the Amish: A Qualitative Analysis of Bias Motivation Using Routine Activities Theory.” Deviant Behavior 23:115-148.

Chasteen, Alison. L., and Jay Pratt. 1999. "The Effect of Age-Related Stereotypes on Response Initiation and Execution.” Journal of General Psychology 127(1):17-37.

Cooksey, Elizabeth, and Joseph Donnermeyer. 2004. "Go Forth and Multiply: Changes in the Timing of Marriage and Childbearing among Young Amish Women.” Paper presented at the Annual Meeting of the Population Association of America. Boston, MA.

Donnermey, Joseph F., Cory Anderson, and Elizabeth Cooksey. 2013. “The Amish Population: County Estimates and Settlement Patterns." Journal of Amish and Plain Anabaptist Studies 1(1):72-109.

Donnermeyer, Joseph F., and David Luthy. 2013. “Amish Settlements across America: 2013.” Journal of Amish and Plain Anabaptist Studies 1(2):107-29.

Dunbar, Edward. 1995. "The Prejudiced Personality, Racism, and Anti-Semitism: The P.R. Scale 40 Years Later.” Journal of Personality Assessment 65(2):270-277.

Fu, Mingying. 2005. "Symbolic Racism of Color: How Asians and Latinos View Affirmative Action." Presented at the Annual Meeting of the Midwest Political Science Association. Chicago, IL.

Gassner, Breanna, and William M. McGuigan. Forthcoming. "Racial Prejudice in College Students: A Cross-Sectional Examination.” College Student Journal. 
Godfrey, Sherrie, Charles L. Richman, and Taryn N. Withers. 2000. "Reliability and Validity of a New Scale to Measure Prejudice: The GRISMS.” Current Psychology: Developmental, Learning, Personality, Social 19:3-20.

Gray, David B., Sheila Connor, and Michael Decatur. 1994. "The Belief in Equality Inventory and Leadership Behavior: A Construct Validation.” Journal of Applied Social Psychology 24:367-377.

Greska, Lawrence P. 2002. "Population Growth and Fertility Patterns in an Old Order Amish Settlement.” Annals of Human Biology 29(2):192-201.

Henry, Patrick J., and David O. Sears. 2008. “Symbolic and Modern Racism.” Pp. 111-112 in Encyclopedia of Race and Racism, Vol. 3, edited by John H. Moore. Macmillan Press.

Jenness, Valerie, David Smith, and Judith Stepan-Norris. 2007. "Religion and Society.” Contemporary Sociology 36(1):vii-viii.

Leibowitz, Barry. 2011. "9 Amish Men in Kentucky Sentenced to Jail in Safety Triangle Case.” CBS News. Retrieved December 28, 2013 (http://www.cbsnews.com).

McConahay, John B. 1986. "Modern Racism, Ambivalence, and the Modern Racism Scale.” Pp. 104-108 in Prejudice, Discrimination and Racism, edited by John F. Dovidio and Samuel L. Gaertner. San Diego, CA: Academic Press.

Mandak, Joe. 2012. “Embattled W. Pa. Amish Sect Moving to Upstate NY.” Associated Press. Retrieved December 12, 2013 (http://www.boston.com).

McGuigan, William M., and Carol Scholl. 2007. "The Effect of Contact on Attitudes toward Old Order Amish.” Journal of Applied Social Psychology 37(11):2642-2659.

Pratto, Felicia, Jim Sidanius, Lisa M. Stallworth, and Bertram F. Malle. 1994. "Social Dominance Orientation: A Personality Variable Predicting Social and Political Attitudes.” Journal of Personality and Social Psychology 67:741-63.

Scheyder, Ernest. 2013. “Amish Sell Royalties to Flee Ohio Oil Boom,” The Columbus Dispatch. Retrieved December 12, 2013 (http://www.dispatch.com).

Swim, Janet K., Kathryn J. Aikin, Wayne S. Hall, and Barbara J. Hunter. 1995. “Sexism and Racism: Old Fashioned and Modern Prejudices.” Journal of Personality and Social Psychology 68:199-214.

Wittenbrink, Bernd, James Hilton, and Pamela Gist. 1998. "In Search of Similarity: Stereotypes as Naive Theories in Social Categorization.” Social Cognition 16(1):331-355. 


\section{Appendix 1: Attitude Towards Amish (A.T.A.) Scale}

Please indicate your immediate and direct response to each item by placing a number corresponding to the scale below in the space provided. There are no incorrect answers.

\begin{tabular}{lllll}
\hline 1 & 2 & 3 & 4 & 5 \\
Strongly Disagree & Disagree & Uncertain & Agree & Strongly Agree \\
\hline
\end{tabular}

1. Intelligence of the Amish ranges from very slow to average to very intelligent.

2. There are plenty of Amish people who are very bright, creative, innovative, flexible, and adaptable.

3. The Amish are skillful and efficient workers.

4. Amish people are skilled problem solvers around the house and farm.

5. Especially in warmer weather, the hot, heavy clothing and bonnets worn by Amish women and children bothers me.

6. I would like having an Amish family for neighbors.

7. The Amish should drive their buggies across their fields and stay off of our roads.

8. Education of Amish children should meet the same state and federal standards of other US schools.

9. I sure hope no one from my family marries an Amish person.

10. If the Amish expect to use our government processes to protect their interests, they should not object to paying the full range of taxes and Social Security.

11. To me, Amish people seem to be unfriendly.

12. As Americans, the Amish have every right to use our roads, hospitals, commerce, police, and fire.

13. Amish people are not as smart as most other Americans.

14. The presence of Amish in any community enhances its economy.

15. Amish people have an offensive odor about them.

16. Amish people are smarter than most Americans because they all speak two languages.

17. It is ridiculous for Amish men to keep their pants closed with pins instead of zippers. 